\title{
Punica granatum Leaf Ethanolic Extract and Ellagic Acid as Inhibitors of Zika Virus Infection
}

Authors

Stefano Acquadro ${ }^{1 *}$, Andrea Civra ${ }^{2 *}$, Cecilia Cagliero ${ }^{1}$, Arianna Marengo ${ }^{1}$, Massimo Rittà ${ }^{2}$, Rachele Francese ${ }^{2}$, Cinzia Sanna ${ }^{3}$, Cinzia Bertea ${ }^{4}$, Barbara Sgorbini ${ }^{1 \mathbb{D}}$, David Lembo ${ }^{2}$, Manuela Donalisio ${ }^{2}$, Patrizia Rubiolo ${ }^{10}$

Affiliations

1 Department of Drug Science and Technology, University of Turin, Turin, Italy

2 Department of Clinical and Biological Sciences, University of Turin, Orbassano, Italy

3 Department of Environmental and Life Sciences University of Cagliari, Cagliari, Italy

4 Department of Life Sciences and Systems Biology, University of Turin, Turin, Italy

Key words

Zika virus, Punica granatum, Lythraceae, leaf ethanolic extract, phytochemical and biomolecular fingerprint, antiviral, ellagic acid

\section{received}

May 22, 2020

accepted after revision

July 30, 2020

published online

September 16, 2020

Bibliography

Planta Med 2020; 86: 1363-1374

DOI 10.1055/a-1232-5705

ISSN 0032-0943

(C) 2020. Thieme. All rights reserved.

Georg Thieme Verlag KG, Rüdigerstraße 14,

70469 Stuttgart, Germany

\section{Correspondence}

Prof. Patrizia Rubiolo

Department of Drug Science and Technology,

University of Turin

Via Pietro Giuria 9, 10125 Turin, Italy

Phone: + 390116707173 , Fax: + 390112367661

patrizia.rubiolo@unito.it

\section{Correspondence}

Prof. Manuela Donalisio

Department of Clinical and Biological Sciences,

University of Turin

Regione Gonzole 10, 10043 Orbassano (To), Italy

Phone: + 390116705427 , Fax: + 390119038639

manuela.donalisio@unito.it
Supporting information available online at

http://www.thieme-connect.de/products

\section{ABSTRACT}

Zika virus, an arthropod-borne flavivirus, is an emerging healthcare threat worldwide. Zika virus is responsible for severe neurological effects, such as paralytic Guillain-Barrè syndrome, in adults, and also congenital malformations, especially microcephaly. No specific antiviral drugs and vaccines are currently available, and treatments are palliative, but medicinal plants show great potential as natural sources of antiZika phytochemicals. This study deals with the investigation of the composition, cytotoxicity, and anti-Zika activity of Punica granatum leaf ethanolic extract, fractions, and phytoconstituents. P. granatum leaves were collected from different areas in Italy and Greece in different seasons. Crude extracts were analyzed and fractionated, and the pure compounds were isolated. The phytochemical and biomolecular fingerprint of the pomegranate leaves was determined. The antiviral activities of the leaf extract, fractions, and compounds were investigated against the MR766 and HPF2013 Zika virus strains in vitro. Both the extract and its fractions were found to be active against Zika virus infection. Of the compounds isolated, ellagic acid showed particular anti-Zika activities, with $\mathrm{EC}_{50}$ values of $30.86 \mu \mathrm{M}$ for MR766 and $46.23 \mu \mathrm{M}$ for HPF2013. The mechanism of action was investigated using specific antiviral assays, and it was demonstrated that ellagic acid was primarily active as it prevented Zika virus infection and was able to significantly reduce Zika virus progeny production. Our data demonstrate the anti-Zika activity of pomegranate leaf extract and ellagic acid for the first time. These findings identify ellagic acid as a possible anti-Zika candidate compound that can be used for preventive and therapeutic interventions.

\footnotetext{
* These authors contributed equally to this work.
} 


\begin{tabular}{|c|c|}
\hline \multicolumn{2}{|c|}{ ABBREVIATIONS } \\
\hline Aut & autumn samples \\
\hline ВНК-21 & baby hamster kidney cell \\
\hline BLAST & basic local alignment search tool \\
\hline BSTFA & N,O-Bis(trimethylsilyl) trifluoroacetamide \\
\hline $\mathrm{CC}_{50}$ & $50 \%$-cytotoxic concentrations \\
\hline $\mathrm{Cl}$ & confidence intervals \\
\hline ESI & electrospray ionization \\
\hline FDA & Food and Drug Administration \\
\hline $\mathrm{HBeAg}$ & hepatitis B e antigen \\
\hline HBV & hepatitis B virus \\
\hline HIV-1 & human immunodeficiency virus type 1 \\
\hline HPV & human papilloma virus \\
\hline HSV-2 & herpes simplex virus type 2 \\
\hline$I_{\mathrm{s}}$ & linear retention indices \\
\hline ITS & internal transcribed spacer \\
\hline MEM & minimum essential medium \\
\hline MOI & multiplicity of infection \\
\hline MTS & $\begin{array}{l}\text { 3-(4,5-Dimethylthiazol-2-yl)-5-(3-carboxy- } \\
\text { methoxyphenyl)-2-(4-sulfophenyl)-2H-tetra- } \\
\text { zolium, inner salt; }\end{array}$ \\
\hline PC & principal component \\
\hline PDA & photo diode array \\
\hline PFU & plaque-forming unit \\
\hline PG & Punica granatum \\
\hline PGL8 & Punica granatum leaf extract 8 \\
\hline Prep & preparative \\
\hline psbA-trnH & chloroplast photosystem II protein D1 \\
\hline RP & reverse phase \\
\hline RSD & relative standard deviation \\
\hline SI & selectivity index \\
\hline SIM & selected ion monitoring \\
\hline SPE & solid phase extraction \\
\hline SRM & selected reaction monitoring \\
\hline Sum & summer samples \\
\hline VACV & vaccinia virus \\
\hline WHO & World Health Organization \\
\hline ZIKV & Zikavirus \\
\hline
\end{tabular}

\section{Introduction}

ZIKV is a mosquito-borne virus that belongs to the Flaviviridae family. It is primarily transmitted by the bite of an infected mosquito from the Aedes genus, mainly Aedes aegypti, in tropical and subtropical regions [1]. Outbreaks of ZIKV disease have been recorded in Africa, the Americas, Asia, and the Pacific, and it is considered a global emerging healthcare threat. Since Aedes albopictus has the capability to be a vector for ZIKV, other countries in temperate regions, such as the Mediterranean basin, are potentially at risk [2]. ZIKV is usually responsible for asymptomatic or mild self-limiting dengue-like diseases, which are characterized by fever, rash, conjunctivitis, arthralgia, and malaise. During the recent outbreak in Brazil, it has been associated with severe neurological effects, such as Guillain-Barré syndrome and meningoencephalitis, in adults, and congenital malformations, espe- cially microcephaly, in infants born to infected mothers [3]. Despite the severity of ZIKV complications, there are currently no FDA-approved vaccines. No specific antiviral drugs are currently available, and treatments are palliative and mainly directed towards the relief of symptoms [1]. For these reasons, new effective preventive and therapeutic strategies against ZIKV infection are urgently needed. Harnessing the potential of medicinal plants as natural sources of anti-ZIKV phytochemicals, such as polyphenols and alkaloids [4], is a complementary and alternative strategy. Punica granatum L. (Lythraceae family), commonly known as pomegranate, is a domesticated tree that is widely grown as an evergreen in tropical regions and as a deciduous tree in temperate areas. It is an ancient plant that is well known in folk medicine and is becoming increasingly popular as a functional food and nutraceutical source due to its high polyphenol content, not only in the edible part, but also in other parts of the fruit and plant, including the peel, bark, leaves, and flowers [5]. Pomegranate is a rich source of a wide variety of compounds with beneficial physiological activities, in particular antioxidative, anti-inflammatory, and anti-cancerous properties [6]. Nearly every part of the plant has been tested for antimicrobial activity, and roles in the suppression of enteric infections, food preservation, wound healing, as well as gut and oral health, have been demonstrated [7]. Most antiviral studies have been performed on the fruit's peel and juice, and it has been found that extracts exerted inhibitory activity against HSV-2, HIV-1, and the influenza virus [8-10]. Little information has been reported on pomegranate leaf extracts, compared to other edible and nonedible parts of the plant, although some recent studies have indicated that they may be an important source of specialized bioactive metabolites and they possess a broad range of biological properties, such as in vitro antioxidant, anti-inflammatory, anticholinesterase, and antiproliferative activities $[5,11,12]$. This study explores the cytotoxicity and anti-ZIKV activity of pomegranate leaf ethanolic extracts, as well as of the corresponding fractions and phytoconstituents after a phytochemical and biomolecular characterization of the leaves, which were collected from various sites, after different vegetative periods, and in different years.

\section{Results and Discussion}

Preliminary tests were carried out on a reference pomegranate leaf ethanolic extract (PGL8) to investigate its anti-ZIKV activity in a specific virus plaque reduction assay against the African lineage strain, 1947 Uganda MR766. A range of extract concentrations were added before and during the infection, as well as after the removal of the virus inoculum. As reported in Fig. 1S, Supporting Information, the extract exerts remarkable antiviral activity, generating dose-response curves. Under these conditions, the extract reduced the number of viral plaques with an $\mathrm{EC}_{50}$ value of $11.4 \mu \mathrm{g} / \mathrm{mL}$ ( $\triangleright$ Table 1 ). To exclude the possibility that antiviral activity was due to cytotoxicity, cells were treated with the serially diluted extract and added to the cell culture medium for $72 \mathrm{~h}$ at $37^{\circ} \mathrm{C}$, and the cellular viability was then determined by MTS assay. The $\mathrm{CC}_{50}$ values were above $100 \mu \mathrm{g} / \mathrm{mL}$, indicating that the antiviral activity observed was not due to cytotoxicity ( $\bullet$ Table 1, Fig. 2 S, Supporting Information). Since the extract was resus- 
- Table 1 Anti-ZIKV-MR766 activity of the pomegranate leaf ethanolic extract (PGL8).

\begin{tabular}{|c|c|c|c|c|c|c|}
\hline Virus & Sample & $\begin{array}{l}\mathrm{EC}_{50} \mathrm{a}(\mu \mathrm{g} / \mathrm{mL}) \\
\left(95 \% \mathrm{Cl}^{b}\right)\end{array}$ & $\begin{array}{l}\mathrm{EC}_{90}{ }^{\mathrm{c}}(\mu \mathrm{g} / \mathrm{mL}) \\
(95 \% \mathrm{Cl})\end{array}$ & $\begin{array}{l}\mathrm{CC}_{50}{ }^{\mathrm{d}}(\mu \mathrm{g} / \mathrm{mL}) \\
(95 \% \mathrm{Cl})\end{array}$ & $\begin{array}{l}\mathrm{CC}_{90}{ }^{\mathrm{e}}(\mu \mathrm{g} / \mathrm{mL}) \\
(95 \% \mathrm{Cl})\end{array}$ & $\mathrm{SI}^{\mathrm{f}}$ \\
\hline MR766 & PGL8 & $11.40(7.84-16.57)$ & $75.32(25.7-113.3)$ & $123.60(104.0-146.7)$ & $443(313.3-559.2)$ & 10.84 \\
\hline HSV-2 & PGL8 & $3.29(1.64-6.56)$ & $120.20(18.5-224.1)$ & $154.90(112.3-213.7)$ & $1633(860-2023.3)$ & 47.08 \\
\hline \multirow[t]{2}{*}{ Vaccinia virus } & PGL8 & n. a. ${ }^{9}$ & n.a & - & - & n.a. \\
\hline & Fractions & $\begin{array}{l}\mathrm{EC}_{50}(\mu \mathrm{g} / \mathrm{mL}) \\
(95 \% \mathrm{Cl})\end{array}$ & $\begin{array}{l}\mathrm{EC}_{90}(\mu \mathrm{g} / \mathrm{mL}) \\
(95 \% \mathrm{Cl})\end{array}$ & $\begin{array}{l}\mathrm{CC}_{50}(\mu \mathrm{g} / \mathrm{mL}) \\
(95 \% \mathrm{Cl})\end{array}$ & $\begin{array}{l}\mathrm{CC}_{90}(\mu \mathrm{g} / \mathrm{mL}) \\
(95 \% \mathrm{Cl})\end{array}$ & SI \\
\hline \multirow[t]{4}{*}{ MR766 } & PGSum85 & $16.20(12.4-21.2)$ & $95.27(45.5-129.5)$ & $76.10(48.4-120)$ & $143(74.5-184.4)$ & 4.69 \\
\hline & PGAut85 & $10.40(7.08-15.2)$ & $43.96(17.3-111.7)$ & 73.40 (51.6-104) & $156(88.3-216.2)$ & 7.05 \\
\hline & PGSum95 & n.a. & n. a. & $14.20(12.3-16.4)$ & $32.20(22.3-46.6)$ & - \\
\hline & PGAut95 & n.a. & n.a. & $17.50(11.9-25.8)$ & $37.20(18-76.6)$ & - \\
\hline
\end{tabular}

pended in a DMSO/ $\mathrm{H}_{2} \mathrm{O}$ solution $(50 \% / 50 \%)$, a control sample with equal volumes of DMSO/ $\mathrm{H}_{2} \mathrm{O}$ was included in all cell-culture experiments in order to rule out the possibility of the solvent having a cytotoxic effect. The SI, which measures the preferential antiviral activity of a drug in relation to its cytotoxicity, was 10.84. Two unrelated DNA viruses, HSV-2 and VACV, were assessed in order to evaluate the antiviral specificity of PGL8. As reported in $>$ Table 1, the extract exerted relevant inhibitory activity against HSV-2, with an SI of 47.08. These data confirmed the anti-HSV-2 effect that had been observed in extracts derived from pomegranate fruit, including the rind and juice [8]. By contrast, we did not observe any inhibition of VACV infectivity.

The characterization of the pomegranate leaf ethanolic extract (sample PGL8) was carried out by HPLC-PDA-MS/MS and GC-MS after derivatization with bis(trimethylsilyl)trifluoroacetamide to obtain trimethylsilyl derivatives, and 3 different chemical classes of specialized metabolites were revealed: phenolics, flavonoids, and triterpenes. A list of the identified and putatively identified compounds is reported in $>$ Table 2 , while the HPLC-PDA and GC-MS profile are found in Figs. 35 and 4S, Supporting Information, respectively. In accordance with the current literature, flavones and flavonols are the most representative specialized metabolites in the extract and often exist as glycosides of luteolin, apigenin, and quercetin. Ellagic acid is the most abundant compound, while hydrolyzable tannins, such as punicalins and punicalagins, which are markers of the other parts of the pomegranate plant, were not detected. In addition, the presence of a pseudomolecular ion at $\mathrm{m} / \mathrm{z} 455$, in negative mode, with a fragment at $\mathrm{m} / \mathrm{z} 407\left(\mathrm{M}-\mathrm{HCHO}-\mathrm{H}_{2} \mathrm{O}-\mathrm{H}\right)^{-}$, and of a pseudomolecular ion at $\mathrm{m} / \mathrm{z} 457$, in negative ionization mode, in the LC-MS profiles indicates the presence of triterpenoid molecules, but with evident coelution. A GC-MS analytical platform was therefore used and enabled oleanolic, betulinic, and ursolic acids to be identified after their derivatization in the extract.

To ensure consistent quality and reproducible activity in the pomegranate leaf extracts, genotypic and phenotypic stability were evaluated by comparing the phytochemical and biomolecular patterns of leaves that belonged to plants of different origins (see Table 1S, Supporting Information) that were harvested in different vegetative periods (summer and autumn) and in different years (2017 and 2018).

HPLC-PDA-MS/MS and GC-MS profiles were qualitatively consistent, and all markers were detected in all of the samples. Quantitation results, reported in Table 2S, Supporting Information, showed differences in the abundances of some compounds in the leaf extracts. The repeatability results showed that RSD\% never exceeded $5 \%$, while intermediate precision in the different extracts showed RSD\% of below $15 \%$. The accuracy of the data was determined by comparing, when available, the UV and MS quantification results, and the RSD\% never exceeded $20 \%$. Principal component analysis was then applied to highlight similarities and differences between the samples. F Fig. 1 reports the score and loading plots of the $\mathrm{PC} 1$ against the $\mathrm{PC2}$, showing homogenous sample distribution in the score plot (no cluster of samples are formed) and a good explained variance (39.14\% for PC1 and $19.72 \%$ for PC2). No clear discrimination between the samples was observed, although the Aut show slightly higher contents of ellagic acid and its hexoside (both positively correlated with PC2, as can be seen in the loading plot). In general, the few differences in the phenolics and triterpenes can be ascribed to phenotypical variability and environmental factors.

To further confirm the quality and reproducibility of the pomegranate leaf extracts, a genotypic fingerprint of the collected leaves was obtained using a DNA barcoding approach [16]. The nuclear ITS region and the psbA-trnH genes were amplified and sequenced for each site from which pomegranate leaf samples were harvested. The sequences were deposited in the GenBank (Table 3S, Supporting Information) and compared to those present in the database ( 59 P. granatum ITS sequences originating from India, Iran, and China and 27 P. granatum psbA-trnH sequences from Iran, Tunisia, China, and Italy [Apulia, Latium, Sardinia, Padua and Trieste]).

Figs. $5 S$ and 65 , Supporting Information, report no variation in the ITS and psbA-trnH nucleotide composition for the 11 sites, suggesting that these biomolecular markers are stable. A consensus sequence for each DNA region was obtained from the align- 
- Table 2 List of identified and putatively identified compounds in leaf extract. Each compound is referred through its relative retention time, UV maxima $\lambda$ absorption, molecular formula, pseudomolecular ions ( $\mathrm{SSI}^{+}$and $\mathrm{ESI}^{-}$), ion fragments generated by Product lon Scan mode (PIS), and identified or tentatively identified compound names. The identification confidence value and the literature reference that indicates the presence of the compounds in pomegranate are also reported.

\begin{tabular}{|c|c|c|c|c|c|c|c|c|c|c|c|}
\hline $\mathbf{N}^{\circ}$ & $\begin{array}{l}\text { RT } \\
\text { (min) }\end{array}$ & $\begin{array}{l}\lambda \max \\
(\mathrm{nm})\end{array}$ & $\begin{array}{l}\text { Molecular } \\
\text { formula }\end{array}$ & {$[\mathrm{M}+\mathrm{H}]^{+}$} & {$[\mathrm{M}-\mathrm{H}]^{-}$} & $\begin{array}{l}\text { Supp. } \\
\text { MW }\end{array}$ & $\begin{array}{l}\mathrm{MS}^{2+} \\
\mathrm{m} / \mathrm{z}\end{array}$ & $\begin{array}{l}\mathrm{MS}^{2-} \\
\mathrm{m} / \mathrm{z}\end{array}$ & $\begin{array}{l}\text { Compound } \\
\text { name }\end{array}$ & $\begin{array}{l}\text { Identif. } \\
\text { conf. }^{\text {b }}\end{array}$ & Ref. \\
\hline $1^{\mathrm{a}}$ & 1.649 & 272 & $\mathrm{C}_{7} \mathrm{H}_{6} \mathrm{O}_{5}$ & 1 & 169 & 170 & & $\begin{array}{l}125 \\
110\end{array}$ & Gallic acid & 1 & [13] \\
\hline 2 & 7.373 & 314 & $\mathrm{C}_{15} \mathrm{H}_{18} \mathrm{O}_{8}$ & 1 & 325 & 326 & & $\begin{array}{l}163 \\
145\end{array}$ & $\begin{array}{l}\text { Coumaric acid } \\
\text { hexoside }\end{array}$ & 2 & [14] \\
\hline 3 & 11.657 & $\begin{array}{l}273 \\
357\end{array}$ & $\mathrm{C}_{13} \mathrm{H}_{8} \mathrm{O}_{8}$ & 1 & 291 & 292 & & 247 & $\begin{array}{l}\text { Brevifolin - } \\
\text { carboxyl acid }\end{array}$ & 2 & [14] \\
\hline 4 & 14.364 & 268 & & $\begin{array}{l}801 \\
151\end{array}$ & 799 & 800 & 151 & 301 & Ellagic derivative & 2 & [13] \\
\hline 5 & 19.032 & $\begin{array}{l}270 \\
350\end{array}$ & & 611 & $\begin{array}{l}935 \\
655 \\
609\end{array}$ & 610 & 151 & $\begin{array}{l}301 \\
137\end{array}$ & Ellagitannin & 3 & \\
\hline 6 & 19.420 & $\begin{array}{l}251 \\
360\end{array}$ & $\mathrm{C}_{20} \mathrm{H}_{16} \mathrm{O}_{13}$ & 465 & 463 & 464 & 1 & 301 & $\begin{array}{l}\text { Ellagic acid } \\
\text { glucoside }\end{array}$ & 2 & [13] \\
\hline 7 & 24.091 & $\begin{array}{l}274 \\
365\end{array}$ & $\mathrm{C}_{41} \mathrm{H}_{28} \mathrm{O}_{27}$ & 953 & 951 & 952 & 1 & $\begin{array}{l}933 \\
301\end{array}$ & $\begin{array}{l}\text { Galloyl- HHDP- } \\
\text { DHHDP-hexoside } \\
\text { (Granatin B) }\end{array}$ & 2 & [13] \\
\hline $8^{a}$ & 24.366 & $\begin{array}{l}253 \\
347\end{array}$ & $\mathrm{C}_{21} \mathrm{H}_{20} \mathrm{O}_{11}$ & 449 & 447 & 448 & 287 & 285 & $\begin{array}{l}\text { Luteolin 7-O- } \\
\text { glucoside }\end{array}$ & 1 & [14] \\
\hline $9^{a}$ & 25.994 & $\begin{array}{l}252 \\
366\end{array}$ & $\mathrm{C}_{14} \mathrm{H}_{6} \mathrm{O}_{8}$ & & 301 & 302 & 1 & $\begin{array}{l}284 \\
229 \\
185\end{array}$ & Ellagic acid & 1 & [13] \\
\hline $9 a^{a}$ & 25.994 & & $\mathrm{C}_{27} \mathrm{H}_{30} \mathrm{O}_{16}$ & 611 & 609 & 610 & & & Rutin & 1 & [13] \\
\hline $10^{\mathrm{a}}$ & 27.426 & $\begin{array}{l}255 \\
353\end{array}$ & $\mathrm{C}_{21} \mathrm{H}_{20} \mathrm{O}_{12}$ & 465 & 463 & 464 & $\begin{array}{l}303 \\
229 \\
153\end{array}$ & $\begin{array}{l}301 \\
255 \\
151\end{array}$ & $\begin{array}{l}\text { Quercetin } \\
\text { 3-O-glucoside }\end{array}$ & 1 & [13] \\
\hline $11^{\mathrm{a}}$ & 28.885 & $\begin{array}{l}266 \\
336\end{array}$ & $\mathrm{C}_{21} \mathrm{H}_{20} \mathrm{O}_{10}$ & 433 & 431 & 432 & 271 & 269 & $\begin{array}{l}\text { Apigenin } \\
\text { 7-O-glucoside }\end{array}$ & 1 & [14] \\
\hline 12 & 30.971 & $\begin{array}{l}268 \\
332\end{array}$ & & 433 & 431 & 432 & 271 & $\begin{array}{l}269 \\
195 \\
151 \\
117\end{array}$ & $\begin{array}{l}\text { Apigenin } \\
\text { glycoside }\end{array}$ & 3 & \\
\hline $13^{\mathrm{a}}$ & 31.719 & $\begin{array}{l}267 \\
337\end{array}$ & $\mathrm{C}_{21} \mathrm{H}_{20} \mathrm{O}_{11}$ & 449 & 447 & 448 & 287 & $\begin{array}{l}285 \\
257\end{array}$ & $\begin{array}{l}\text { Luteolin } \\
\text { 4'-O-glucoside }\end{array}$ & 1 & [13] \\
\hline 14 & 33.223 & $\begin{array}{l}268 \\
340\end{array}$ & & 449 & 447 & 448 & $\begin{array}{l}287 \\
153\end{array}$ & $\begin{array}{l}285 \\
151\end{array}$ & $\begin{array}{l}\text { Luteolin } \\
\text { glycoside } 1\end{array}$ & 3 & \\
\hline 15 & 37.253 & $\begin{array}{l}268 \\
340\end{array}$ & & 419 & 417 & 418 & $\begin{array}{l}287 \\
153\end{array}$ & $\begin{array}{l}285 \\
257 \\
175 \\
151\end{array}$ & $\begin{array}{l}\text { Luteolin } \\
\text { glycoside } 2\end{array}$ & 3 & \\
\hline $16^{\mathrm{a}}$ & 42.958 & $\begin{array}{l}252 \\
347\end{array}$ & $\mathrm{C}_{15} \mathrm{H}_{10} \mathrm{O}_{6}$ & 287 & 285 & 286 & $\begin{array}{l}153 \\
135 \\
117\end{array}$ & $\begin{array}{l}171 \\
151 \\
133 \\
115\end{array}$ & Luteolin & 1 & [13] \\
\hline $17^{\mathrm{a}}$ & 45.538 & $\begin{array}{l}267 \\
336\end{array}$ & $\mathrm{C}_{15} \mathrm{H}_{10} \mathrm{O}_{5}$ & 271 & 269 & 270 & $\begin{array}{l}163 \\
153 \\
119\end{array}$ & $\begin{array}{l}151 \\
117\end{array}$ & Apigenin & 1 & [14] \\
\hline * & 50.201 & - & $\mathrm{C}_{30} \mathrm{H}_{48} \mathrm{O}_{3}$ & 457 & 455 & 456 & $\begin{array}{l}333 \\
239 \\
191 \\
189\end{array}$ & 407 & Oleanolic acid & 1 & [14] \\
\hline
\end{tabular}

cont. 
- Table 2 Continued

\begin{tabular}{|c|c|c|c|c|c|c|c|c|c|c|c|}
\hline $\mathbf{N}^{\circ}$ & $\begin{array}{l}\text { RT } \\
(\min )\end{array}$ & $\begin{array}{l}\lambda \max \\
(\mathrm{nm})\end{array}$ & $\begin{array}{l}\text { Molecular } \\
\text { formula }\end{array}$ & {$[\mathrm{M}+\mathrm{H}]^{+}$} & {$[\mathrm{M}-\mathrm{H}]^{-}$} & $\begin{array}{l}\text { Supp. } \\
\text { MW }\end{array}$ & $\begin{array}{l}\mathrm{MS}^{2+} \\
\mathrm{m} / \mathrm{z}\end{array}$ & $\begin{array}{l}\mathrm{MS}^{2-} \\
\mathrm{m} / \mathrm{z}\end{array}$ & $\begin{array}{l}\text { Compound } \\
\text { name }\end{array}$ & $\begin{array}{l}\text { Identif. } \\
\text { conf. }^{\text {b }}\end{array}$ & Ref. \\
\hline * & 50.201 & - & $\mathrm{C}_{30} \mathrm{H}_{48} \mathrm{O}_{3}$ & 457 & 455 & 456 & $\begin{array}{l}333 \\
239 \\
191 \\
189\end{array}$ & 407 & Betulinic acid & 1 & [14] \\
\hline$*$ & 50.201 & - & $\mathrm{C}_{30} \mathrm{H}_{48} \mathrm{O}_{3}$ & 457 & 455 & 456 & $\begin{array}{l}333 \\
239 \\
191 \\
189\end{array}$ & 407 & Ursolic acid & 1 & [14] \\
\hline
\end{tabular}

${ }^{a}$ Compounds identified by comparing with reference standards; ${ }^{b}$ An identification confidence according to the request of the Chemical Analysis Working Group (CAWG, 2007) [15] is indicated: Level 1:Identified compound (A minimum of 2 independent orthogonal data (such as retention time and mass spectrum) compared directly to an authentic reference standard; Level 2: Putatively annotated compound (compound identified by analysis of spectral data and similarity to bibliographic data); Level 3: putatively characterized class compound; Level 4: unknown compound.

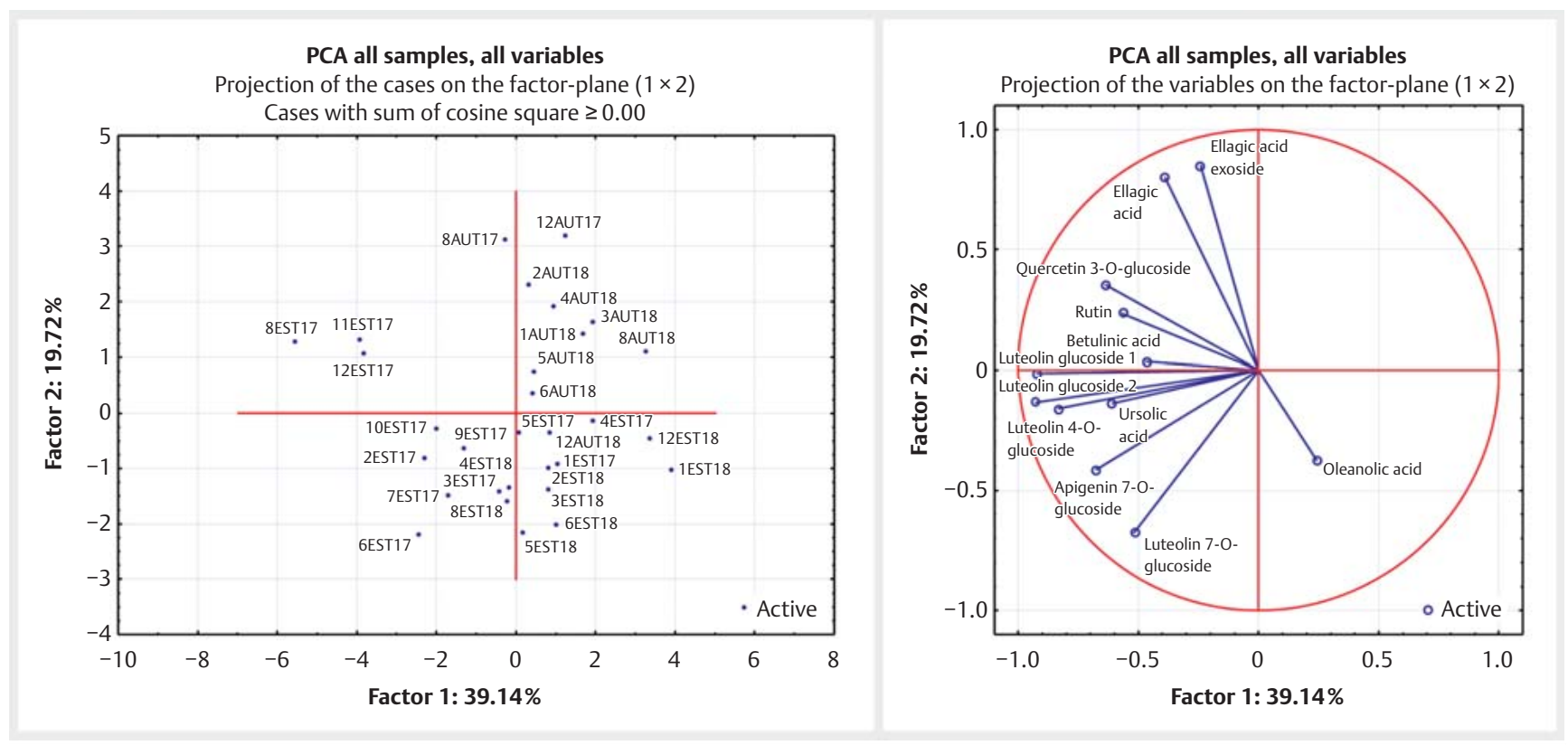

Fig. 1 Score plot (a) and loading plot (b) of the principal component analysis relative to the quantity of the main markers of the pomegranate's leaf extracts.

ment of all the samples. A BLAST alignment of the consensus, with all the data present in the database, showed a percentage of identity among the $P$. granatum sequences that ranged from $100 \%$ to $96.89 \%$ for ITS, and from $100 \%$ to $97.64 \%$ for psbA-trnH, confirming intraspecies stability and higher interspecies variability. Interestingly, the comparison with psbA-trnH from Italian regions (accession numbers: HG765008, HG765007, HG765006, HG765005), showed $100 \%$ similarity, supporting the stability of the species in Italy.

Based on the data obtained from the phytochemical characterization, representative summer and autumn pool extracts were created.

A bio-guided fractionation procedure was performed to attribute the antiviral activity to a specific fraction and/or single com- ponents of the pomegranate leaf extracts. The summer and autumn extracts were submitted to SPE fractionation, resulting in 2 fractions: a phenolic fraction (yield $73 \%$ ) eluted with methanol/ water 85:15 (PGAut85, PGSum85), and a triterpenoid fraction (yield 5\%) eluted with methanol/water 95:05 (PGAut95, PGSum95). Table 2S, Supporting Information, reports the qualiquantitative composition of the 4 samples. The phenolic fraction was characterized by ellagic acid, rutin, apigenin, quercetin, and luteolin glycosides. In the PGAut85 fraction, ellagic acid was the most abundant compound, while, in the PGSum85 one, luteolin 4'-O-glucoside was the main compound, although a good amount of ellagic acid was detected. The triterpenoid fraction was characterized by oleanolic, betulinic, and ursolic acids. 
- Table 3 Anti-ZIKV-MR766 activity of phenolic and triterpenic compounds. For each concentration tested, the percentage of infection in comparison to control is reported as mean value \pm SD. The molarities of the compounds is reported in square brackets, referred to $3.7 \mu \mathrm{g} / \mathrm{mL}, 11 \mu \mathrm{g} / \mathrm{mL}$, and $33 \mu \mathrm{g} / \mathrm{mL}$ concentrations, respectively.

\begin{tabular}{|l|c|c|c|}
\hline Compounds & $\mathbf{3 . 7 \mu g} / \mathbf{m L}$ & $\mathbf{1 1} \mathbf{\mu g} / \mathbf{m L}$ & $\mathbf{3 3} \mathbf{\mu g} / \mathbf{m L}$ \\
\hline Apigenin & $99.0 \pm 7.1[13.7 \mu \mathrm{M}]$ & n. a. ${ }^{\mathrm{a}}[40.7 \mu \mathrm{M}]$ & n. a. $[122.1 \mu \mathrm{M}]$ \\
\hline Apigenin 7-O-glucoside & $103.6 \pm 8.9[8.5 \mu \mathrm{M}]$ & $101.2 \pm 3.7[25.4 \mu \mathrm{M}]$ & $102.5 \pm 2.8[76.2 \mu \mathrm{M}]$ \\
\hline Betulinic acid & $99.3 \pm 1.1[8.1 \mu \mathrm{M}]$ & $101.5 \pm 6.4[24.1 \mu \mathrm{M}]$ & $95.5 \pm 10.7[72.3 \mu \mathrm{M}]$ \\
\hline Luteolin & $102.9 \pm 4.1[13 \mu \mathrm{M}]$ & n. a. $[38.5 \mu \mathrm{M}]$ & n. a. $[115.5 \mu \mathrm{M}]$ \\
\hline Luteolin 4-O-glucoside & $103.0 \pm 1.4[8.3 \mu \mathrm{M}]$ & $96.0 \pm 5.7[24.5 \mu \mathrm{M}]$ & $102.8 \pm 8.8[73.6 \mu \mathrm{M}]$ \\
\hline Luteolin 7-O-glucoside & $105.0 \pm 5.7[8.3 \mu \mathrm{M}]$ & $102.0 \pm 11.3[24.5 \mu \mathrm{M}]$ & $100.0 \pm 3.3[73.6 \mu \mathrm{M}]$ \\
\hline Oleanolic acid & $99.5 \pm 9.2[8.1 \mu \mathrm{M}]$ & $103.8 \pm 3.2[24.1 \mu \mathrm{M}]$ & $104.3 \pm 6.7[72.3 \mu \mathrm{M}]$ \\
\hline Quercetin 3-O-glucoside & $105.5 \pm 6.4[8.0 \mu \mathrm{M}]$ & $103.1 \pm 9.8[23.8 \mu \mathrm{M}]$ & $106.5 \pm 4.6[71.3 \mu \mathrm{M}]$ \\
\hline Rutin & $103.3 \pm 9.5[6.1 \mu \mathrm{M}]$ & $95.4 \pm 20.6[18.0 \mu \mathrm{M}]$ & $107 \pm 2.4[54.1 \mu \mathrm{M}]$ \\
\hline Ursolic acid & $100.0 \pm 11.9[8.1 \mu \mathrm{M}]$ & $79.7 \pm 2.3[24.1 \mu \mathrm{M}]$ & n. a. $[72.3 \mu \mathrm{M}]$ \\
\hline Ellagic acid & $83.8 \pm 11.5[12.2 \mu \mathrm{M}]$ & $43.3 \pm 1.3[36.4 \mu \mathrm{M}]$ & $0.0 \pm 0.0[109.2 \mu \mathrm{M}]$ \\
\hline
\end{tabular}

Betulinic acid, oleanolic acid, ursolic acid, apigenin were resuspended in a DMSO/ $\mathrm{H}_{2} \mathrm{O}$ solution (70\%/30\%); apigenin 7-O-glucoside, luteolin, luteolin 4-Oglucoside, luteolin 7-O-glucoside, quercetin 3-O-glucoside, rutin, and ellagic acid were were resuspended in a DMSO solution. an. a.: not assessable

- Table 4 Anti-ZIKV activity of ellagic acid.

\begin{tabular}{|c|c|c|c|c|c|}
\hline & Virus & $\mathrm{EC}_{50}{ }^{\mathrm{a}}(\mu \mathrm{M})\left(95 \% \mathrm{Cl}^{\mathrm{b}}\right)$ & $\mathrm{EC}_{90}{ }^{\mathrm{c}}(\mu \mathrm{M})\left(95 \% \mathrm{Cl}^{\mathrm{b}}\right)$ & $\mathrm{CC}_{50}{ }^{\mathrm{d}}(\mu \mathrm{M})$ & $\mathrm{Sl}^{\mathrm{e}}$ \\
\hline \multirow[t]{2}{*}{ Commercial ellagic acid } & MR766 & $36.22(28.91-45.37)$ & $93.05(53.17-162.8)$ & 496.5 & 13.7 \\
\hline & HPF2013 & $20.99(16.48-26.74)$ & $53.23(31.11-91.09)$ & 496.5 & 23.7 \\
\hline \multirow[t]{2}{*}{ Isolated ellagic acid } & MR766 & $30.86(26.02-36.6)$ & $42.64(33.98-53.51)$ & 446.85 & 14.5 \\
\hline & HPF2013 & $46.23(37.88-56.41)$ & $141.2(85.90-232.0)$ & 446.85 & 9.7 \\
\hline
\end{tabular}

a $\mathrm{EC}_{50}$ : half maximal effective concentration; ${ }^{\mathrm{b}} \mathrm{Cl}$ : confidence interval; ${ }^{\mathrm{c}} \mathrm{EC}_{90}$ : $90 \%$ effective concentration; ${ }^{\mathrm{d}} \mathrm{CC}_{50}$ : half maximal cytotoxic concentration;

e SI: selectivity index. Ellagic acid was resuspended in a DMSO solution.

As reported in > Table 1 and Fig. 7S, Supporting Information, both the PGAut85 and PGSum85 fractions were active against ZIKV at increasing doses with $E_{50}$ values of 10.40 and $16.20 \mu \mathrm{g} /$ $\mathrm{mL}$, respectively. However, no PG95 fractions exerted antiviral activity. No statistical differences were observed in the $\mathrm{EC}_{50}$ values of the summer and autumn fractions, confirming the demonstrated similar chemical compositions of the pomegranate leaves. The main components of the PG85 and PG95 fractions were therefore tested. A preliminary screening was performed to test the activity of the phenolic and triterpenic compounds at 3 doses $(33,11$, $3.7 \mu \mathrm{g} / \mathrm{mL}$ ) against the MR766 strain by treating cells before, during, and after infection. > Table $\mathbf{3}$ demonstrates that ellagic acid was active against ZIKV infection in a dose-dependent manner. No inhibitory effect was observed at any dose for the other compounds. These data, obtained on cell cultures, did not confirm the predictive inhibitory activity of luteolin, apigenin, and rutin as inhibitors of the ZIKV NS2B-NS3 protease, as identified by molecular docking $[17,18]$. Furthermore, the ability of quercetin 3-O-glucoside to inhibit ZIKV in vitro, as reported in the literature, was not reproduced [19]. According to our data, ellagic acid showed the highest antiviral activity against ZIKV and was therefore isolated from the pomegranate extract by Prep-LC and se- lected for further study. The isolated ellagic acid was characterized by ${ }^{1} \mathrm{H}$ NMR, and its spectrum compared with that of the commercial standard (Fig. 8S, Supporting Information). The purity of the compound was determined by HPLC-PDA and calculated to be $>97 \%$.

To confirm the inhibition of ZIKV infectivity that the isolated ellagic acid demonstrated in the preliminary standard plaque reduction assay, a wider range of concentrations was tested against the MR766 strain in order to determine the $\mathrm{EC}_{50}$ values. High inhibitory activity was observed with an $\mathrm{EC}_{50}$ value of $30.86 \mu \mathrm{M}$ ( $\vee$ Table 4, Fig. 2a). It is worth noting that the compound was also active against the Asian lineage strain, 2013 French Polynesia HPF2013, with an $\mathrm{EC}_{50}$ of $46.23 \mu \mathrm{M}$, indicating the broad spectrum of its action against different ZIKV strains. These data were confirmed using the commercially available standard, endowed with comparable $\mathrm{EC}_{50}$ values ( $\vee$ Table $\mathbf{4}$ and Fig. $\mathbf{2}$ b). To corroborate the inhibition of ZIKV infectivity by ellagic acid, immunofluorescence experiments that incubated fixed cells with a flavivirus group antigen antibody, were performed in the same conditions as described previously for both MR766 and HPF2013. As reported in $\mathbf{F i g s .} \mathbf{2} \mathbf{c}$ and $\mathbf{d}$, the analysis by confocal laser scanning microscope revealed a strong red signal from ZIKV protein E in the 


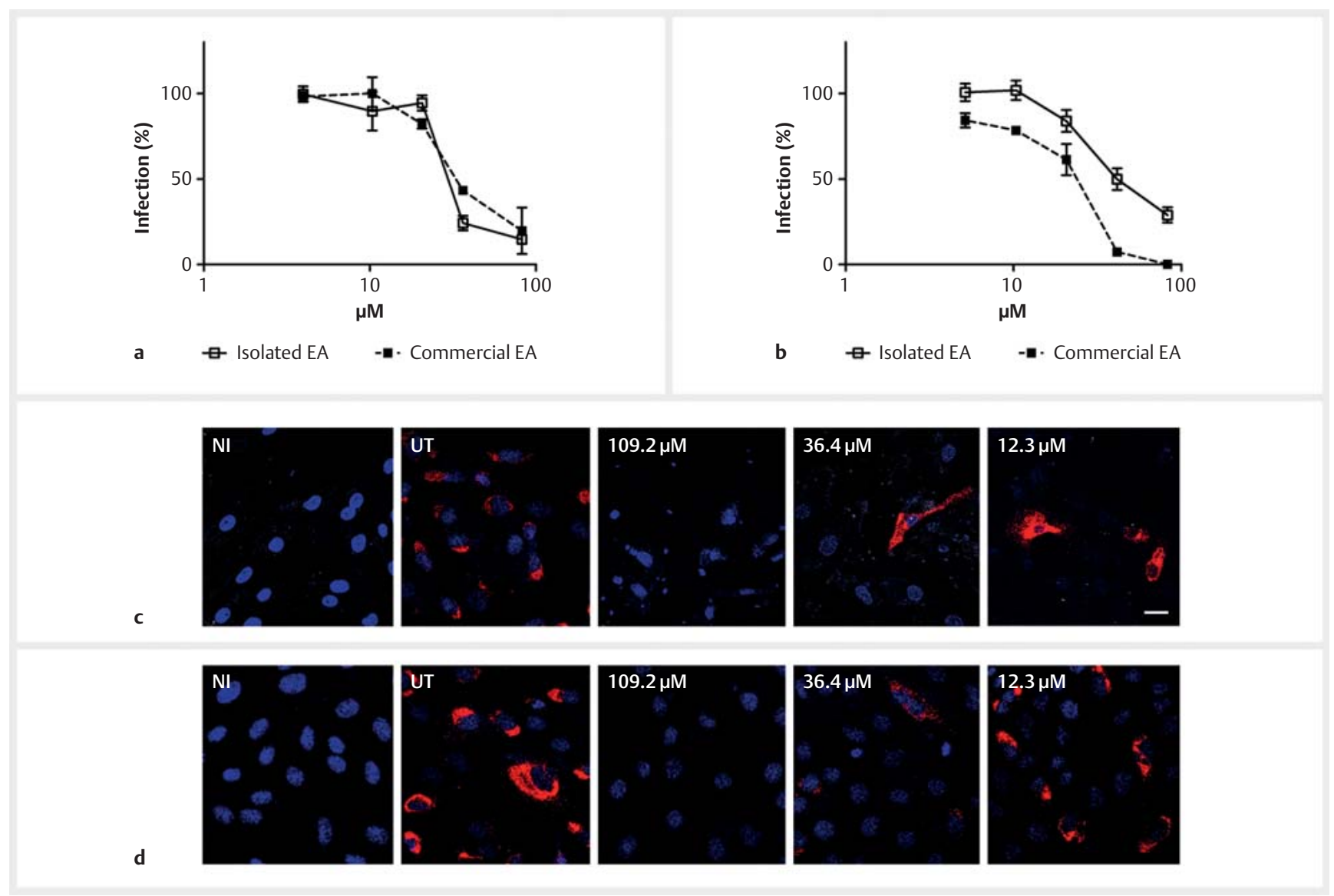

- Fig. 2 Panels a and b. Plaque reduction assays infecting cells with MR766 (panel a) and HPF2013 (panel b) in the presence of isolated and commercial ellagic acid. Vero cells were treated with ellagic acid prior to infection, during the infection period, and after the infection for $72 \mathrm{~h}$. Results are reported as percentage of infection in comparison to untreated controls ( $\mathrm{Y}$-axis); the concentrations tested are reported on $\mathrm{X}$-axis. Error bars represent the standard error of the mean for 3 independent experiments. Panel c and d. Representative MR766 foci (panel c) and HPF2013 foci (panel d) in Vero cells by immunofluorescence assay. Vero cells were treated with ellagic acid before, during, and after the infection. The ZIKV protein $\mathrm{E}$ is visualized in red, nuclei in blue. NI: not infected; UT: untreated. Scale bar, $20 \mu \mathrm{m}$. Ellagic acid was resuspended in a DMSO solution.

cytosol of untreated cells. A dose-dependent signal was observed in treated cells; the highest tested dose $(109.2 \mu \mathrm{M})$ completely inhibited the infectivity of both strains, while the number of infected cells was considerably reduced at $36.4 \mu \mathrm{M}$.

Recently, the antiviral activity of ellagic acid, which had been isolated from other plants, has been demonstrated in vitro against different RNA viruses, such as the influenza virus, Ebola virus, hepatitis C virus, and HIV-1 [20-23]. Furthermore, ellagic acid has revealed potential activity against HBV infection due to its hepatoprotective properties and ability to effectively block HBeAg secretion in cells [24]. By contrast, ellagic acid partially inhibited HSV-2 infection [8]. Herein, we have demonstrated, for the first time, the antiviral activity of pomegranate-derived ellagic acid against ZIKV, a member of the Flaviviridae family. Previously, other polyphenols, such as delphinidin and epigallocatechin gallate, have been shown to have antiflaviviral effects [25]. Our data have demonstrated that the isolated ellagic acid inhibited, in vitro, the infection of 2 lineages, the African one, which is responsible for more acute infection, and Asian ZIKV, which is associated with neurological impairments [26]. Interestingly, the compound also exerted adulticidal activity against Aedes aegypti mosquito, the main vector of the virus [27].

As ellagic acid was identified as an inhibitor compound of ZIKV infectivity, further studies were performed to elucidate its mechanism of action. Firstly, we tested the ability of isolated ellagic acid to reduce ZIKV progeny production in vitro by performing a virus yield reduction assay. The experimental procedure for this assay is similar to the one described for the viral plaque reduction assay, but the viral titers of the samples were evaluated after infection. As reported in - Fig. 3, 109.2 and 36.4 $\mu \mathrm{M}$ concentrations significantly reduced the production of infectious viruses 100 and 10 -fold, respectively.

A virucidal assay was performed to investigate the possible direct virus-inactivating activity of the isolated compound on both MR766 and HPF2013. To this aim, $10^{5}$ pfu of the ZIKV strains and the compound, at the dose corresponding to the $\mathrm{EC}_{90}$ values, were mixed and incubated for $2 \mathrm{~h}$ at either 4 or $37^{\circ} \mathrm{C}$. As reported in Fig. 9S, Supporting Information, no inhibition by the isolated ellagic acid was observed under any experimental conditions either for MR766 or HPF2013, thus excluding the possibility that the di- 


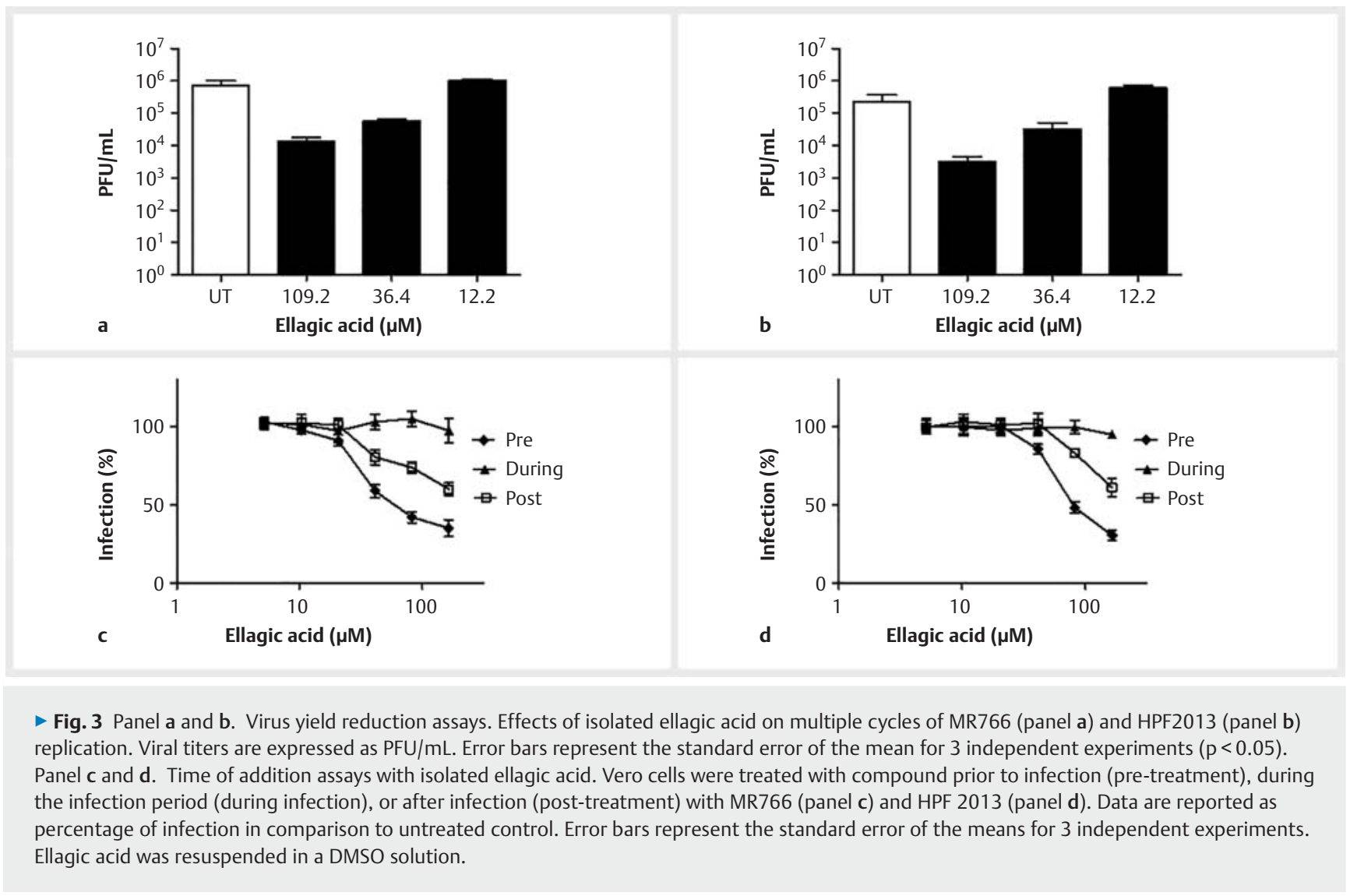

rect inactivation of extracellular virus particles may be a mode of antiviral action. The time-of-addition assay allowed us to investigate the stage of the virus replication cycle at which the compound acts by targeting the cellular surface or intracellular processes. To this aim, the compound was added to the cells at different times of infection only before, during, or after infection. In all of the experiments, DMSO-treated infected cells were used as controls, and plaque-formation inhibition was evaluated.

- Fig. $3 \mathrm{c}$ shows that the isolated compound exerted inhibitory activity against the MR766 strain in a dose-response manner, when added $2 \mathrm{~h}$ before infection, with an $\mathrm{EC}_{50}$ value of $74.48 \mu \mathrm{M}$. By contrast, inhibition was absent in the during-treatment assay, whereas weak inhibition was observed at the higher doses tested in the post-treatment assay. These data were confirmed using the HPF2013 (panel d) strain with inhibitory activity being observed in the pre-treatment assay with a value of $93.01 \mu \mathrm{M}$. The ability to inhibit viral infection during the pre-treatment assay was also observed when cells were treated with the commercial compound (data not shown). These data suggest that ellagic acid primarily reduces cell susceptibility to virus infection by tethering to the cell surface.

Our results demonstrate that ellagic acid did not affect the ZIKV infection by directly inactivating the virus particles. The time-of-addition experiments indicated that ellagic acid, added before viral exposure, suppressed viral replication, which suggests that, mechanistically, the compound interferes with the cell surface, likely masking ZIKV receptors, including AxI9, on target cells, prior to viral/cell membrane fusion. Similar ellagic acid activity was observed against HIV-1. However, in this case, it was also shown to be able to specifically block viral integrase activity [21]. Furthermore, ellagic acid has been observed to have a HPV-preventive effect in clinical trials; women treated with the ellagic acid complex were less likely to be diagnosed with an abnormal Pap smear at 6 months [28].

The absence of activity when the compound was added, with the virus, to the cells indicates that it did not impair the early intracellular steps of viral replication or viral targets. This hypothesis was confirmed by performing a binding assay, and it was shown that a high concentration of isolated compound did not inhibit the binding of either MR766 or HPF2013 to the host-cell surface (Fig. 10S, Supporting Information).

Further studies are required to clarify whether the anti-ZIKV activity of ellagic acid may also occur indirectly via an alteration in the innate response of the infected target cells. In recent years, ellagic acid has gained attention due to its antioxidant, anticancer, anti-allergic, and anti-inflammatory activities. Its antioxidant properties have been associated with hepatoprotective activity, the attenuation of liver injury during hepatitis B infection, and with therapeutic effects on the survival of influenza-challenged mice, in combination with an antiviral drug and an immunomodulator $[29,30]$.

Our current data suggest that ellagic acid may be a promising candidate for the development of a novel anti-ZIKV compound. 
Further structural modifications might be needed to improve its selectivity index.

In summary, we have demonstrated, for the first time, that pomegranate leaf extract and its fractions possess anti-ZIKV activity. The lack of a protective vaccine and specific treatment against ZIKV has prompted us to develop safe and effective anti-ZIKV compounds that are also able to prevent infection by impairing the chain of congenital transmission. The pomegranate leaf ethanolic extract is characterized by hydrolyzable tannins, flavonoids, and triterpenes; its phytochemical pattern is stable and does not depend on geographical conditions or season. Furthermore, no differences were found in the ITS and psbA-trnH sequences extracted from leaves collected in different sites. Moreover, leaf collection is sustainable as it does not cause damage to the plant during spring pruning or in the fall. Ellagic acid was identified, from among the isolated constituents, as an interesting antiviral compound for its inhibitory activity, and its ability to prevent infection and reduce the transmission of extracellular free virus at high titers. Further work must still be done to elucidate the cellular targets involved in this antiviral action and to assess ellagic acid's clinical potential as a preventive and/or therapeutic compound.

\section{Materials and Methods}

\section{Plant materials}

$P$. granatum leaves were collected from different sites in Sardinia, and occasionally other Italian regions, and in Greece from June to October 2017 and 2018 (Table 1S, Supporting Information). Sample 8 was from the botanical garden of the University of Cagliari, Italy. All individuals sampled from other sites were collected randomly. Voucher specimens (Table 1S, Supporting Information) were deposited at the Cagliari's botanical garden and at the Department of Drug Science and Technology of the University of Turin. The fresh plant materials were dried at $40{ }^{\circ} \mathrm{C}$ to constant weight.

\section{Chemicals}

LC-MS grade acetonitrile, HPLC-grade methanol, pyridine, BSTFA, formic acid (>98\% purity), ellagic acid, rutin, and apigenin were purchased from Merck. De-ionized water $(18.2 \mathrm{M} \Omega \mathrm{cm})$ was obtained from a Milli-Q purification system (Millipore). Luteolin, apigenin 7-O-glucoside, quercetin 3-O-glucoside, luteolin 7-O-glucoside, luteolin 4'-O-glucoside, betulinic acid, oleanolic acid, and ursolic acid were obtained from Extrasynthese.

\section{Ethanolic extract preparation}

Two extracts were prepared from each sample; $0.500 \mathrm{~g}$ of dried and ground powder was extracted using an ultrasonic bath (Soltec, Sonica S3 EP 2400) operating at $40 \mathrm{KHz}$ with $10 \mathrm{~mL}$ of ethanol, 3 times for $10 \mathrm{~min}$ each. The supernatants were combined and centrifuged at $5000 \mathrm{rpm}$ for $10 \mathrm{~min}$, poured into a glass balloon, and evaporated in a rotary evaporator under vacuum at a temperature below $50^{\circ} \mathrm{C}$. In order to reduce chlorophyll interference, $30 \mathrm{mg}$ of crude extract were resuspended in $1 \mathrm{~mL}$ of methanol/water $(20: 80, v / v)$, loaded onto a Bond Elut Jr $500 \mathrm{mg}$ SPE-C18 cartridge (Agilent Technologies), eluted with $8 \mathrm{~mL}$ of methanol/water $(95: 5, \mathrm{v} / \mathrm{v})$, and evaporated in a rotary evaporator. Pool samples, obtained by mixing the leaves that were harvested in summer (PGSum) and autumn (PGAut), were also created and extracted in the same way.

\section{HPLC-PDA-MS/MS analysis}

For each extract, a $10 \mathrm{mg} / \mathrm{mL}$ stock solution in methanol was prepared, subsequently diluted with acetonitrile/water $(95: 5, \mathrm{v} / \mathrm{v})$, and filtered through a $13 \mathrm{~mm}$ diameter, $0.22 \mu \mathrm{m}$ PTFE syringe hydrophilic filter before HPLC-PDA-MS/MS analyses. Each extract $(5 \mu \mathrm{L})$ was analyzed using a Shimadzu Nexera X2 system equipped with a photodiode array detector SPD-M20A that was connected, in series, to a Shimadzu LCMS-8040 triple quadrupole system outfitted with an ESI source (Shimadzu). The chromatographic conditions were: column: Ascentis Express RP-Amide $(10 \mathrm{~cm} \times 2.1 \mathrm{~mm}$, $2.7 \mu \mathrm{m}$, Supelco); mobile phases: A water/formic acid (999:1, v/v) and $B$ acetonitrile/formic acid (999: 1, v/v); flow rate: $0.4 \mathrm{~mL} / \mathrm{min}$; column temperature: $30{ }^{\circ} \mathrm{C}$; gradient: $5 \%$ B for $5 \mathrm{~min}, 5-25 \% \mathrm{~B}$ in $35 \mathrm{~min}, 25-100 \%$ B in $10 \mathrm{~min}, 100 \%$ B for $1 \mathrm{~min}$. UV spectra were acquired over the $220-450 \mathrm{~nm}$ wavelength range. The mass spectrometer operation conditions and identification criteria were as reported by Marengo et al. [31]. Quantitation was performed using the external standard calibration method via UV (at the $\lambda$ max for each compound) and SRM acquisition in $\mathrm{ESI}^{+}$(collision energy: 35.0 $\mathrm{V}$ for $\mathrm{ESI}^{+}$, dwell time: 20). The results are expressed as $\mathrm{mg}$ of compound per $\mathrm{g}$ of dried leaves $(\mathrm{mg} / \mathrm{g})$. When the commercial standard was not available, quantification was based on the UV calibration curves of compounds belonging to the same chemical class. The calibration ranges, $\lambda$ max, SRM transitions, and analytical performance of the method are reported in Table 5S, Supporting Information. Analyses were performed in triplicate. All data were processed using LabSolution software (Shimadzu).

\section{GC-MS analysis}

GC analysis were carried out on a Shimadzu 2010 GC unit that was coupled to a Shimadzu QP2010 Mass spectrometer and that made use of a MPS-2 multipurpose sampler (Gerstel). The derivatization of the extracts was performed with bis(trimethylsilyl)trifluoroacetamide to obtain trimethylsilyl derivatives, as reported by Rubiolo et al. [32]. GC-MS analyses were carried out on a MEGA-1 column ( $100 \%$ methylpolysiloxane, $15 \mathrm{~m} \times 0.18 \mathrm{~mm}_{c}, 0.18 \mu \mathrm{m} d_{f}$ ) from MEGA S. r. I. (Milan, Italy). Analytical conditions: injector temperature: $300^{\circ} \mathrm{C}$, transfer line temperature: $320^{\circ} \mathrm{C}$, carrier gas: $\mathrm{He}$ $(0.8 \mathrm{ml} / \mathrm{min})$, split ratio $1: 10$. Temperature program: $50^{\circ} \mathrm{C}$ $(2 \mathrm{~min}) / / 5^{\circ} \mathrm{C} / \mathrm{min} / / 300^{\circ} \mathrm{C}$. MS conditions: source temperature: $200^{\circ} \mathrm{C}$, ionization mode: electron impact $(70 \mathrm{eV})$, scan rate: $0.2 \mathrm{u} / \mathrm{s}$, mass range: $100-650 \mathrm{~m} / \mathrm{z}$. Compounds were identified via comparisons of mass spectra and $I_{\mathrm{s}}$, calculated versus a C9C25 hydrocarbon mixture, with those reported in the literature. The identity of the triterpenoids was confirmed by the co-injection of commercially available standards. The quantitation of the triterpenoids was performed in SIM-acquisition mode using the external standard calibration method, according to Rubiolo et al. [32] (Table 6S, Supporting Information). Data were processed using Shimadzu GCMS Solution software (Shimadzu) 


\section{DNA extraction, PCR amplification and sequencing}

The DNA extraction, PCR amplification, and sequencing of the ITS and psbA-trnH regions were performed according to Marengo et al. [16] without modifications. Table 4S, Supporting Information, reports the list of primers used in PCR and sequencing.

\section{SPE-C18 cartridge and Prep-LC fractionation}

Crude PGSum and PGAut ethanolic extracts were fractionated using a SPE-C18 cartridge: $30 \mathrm{mg}$ of each crude extract were resuspended in $1 \mathrm{~mL}$ of methanol/water $(20: 80, \mathrm{v} / \mathrm{v})$, loaded onto the Bond Elut Jr $500 \mathrm{mg}$ SPE-C18 cartridge, first eluted with $5 \mathrm{~mL}$ of methanol/water $85: 15, \mathrm{v} / \mathrm{v}$ (PG85) and subsequently with $5 \mathrm{~mL}$ of methanol/water 95:05, v/v (PG95). Both fractions were evaporated to dryness. Fraction PGAut85, at a concentration of $40 \mathrm{mg} /$ $\mathrm{mL}$, was injected into a Shimadzu LC-10AT system to isolate the ellagic acid. Chromatographic conditions: column: Ascentis Express RP-Amide $(15 \mathrm{~cm} \times 10 \mathrm{~mm}, 5 \mu \mathrm{m}$, Supelco) mobile phases: see HPLC-PDA-MS/MS analysis; flow rate: $1 \mathrm{~mL} / \mathrm{min}$; column temperature: $30^{\circ} \mathrm{C}$; gradient program: $10 \% \mathrm{~B}$ for $1 \mathrm{~min}, 10-30 \% \mathrm{~B}$ in $60 \mathrm{~min}, 30-51 \% \mathrm{~B}$ in $9 \mathrm{~min}, 51-100 \% \mathrm{~B}$ in $1 \mathrm{~min}, 100 \% \mathrm{~B}$ for 4 min; injection volume: $100 \mu \mathrm{L}$. Ellagic acid was collected via multiple injections, the organic solvent was evaporated with a rotary evaporator, and the sample was subsequently freeze-dried. The purity of the isolated ellagic acid was confirmed via a HPLCPDA-MS/MS analysis at a concentration of $1 \mathrm{mg} / \mathrm{ml}$ in methanol and was calculated as a percentage peak area at $254 \mathrm{~nm}$. Isolated and commercial ellagic acid were also characterized by ${ }^{1} \mathrm{H}$ NMR. Spectra were collected in deuterated DMSO using a JEOL ECZR600 $(600 \mathrm{MHz})$ nuclear magnetic resonance (NMR) spectrometer.

\section{Cell cultures}

African green monkey fibroblastoid kidney cells (Vero cells, ATCC CCL-81) were grown as monolayers in Eagle's MEM (Sigma-Aldrich) with $10 \%$ heat-inactivated FBS (Sigma-Aldrich) and $1 \%$ antibiotic solution (penicillin-streptomycin, Sigma-Aldrich) in a humidified $5 \% \mathrm{CO}_{2}$ atmosphere at $37^{\circ} \mathrm{C}$. The antiviral assays, against ZIKV and HSV-2, were performed on Vero cells. BHK-21 cells (ATCC CCL-10) were grown in DMEM 10\% FBS and used for antiviral assays against the VACV. The embryonic human kidney cells (293 T) (ATCC CRL-3216) were grown as monolayer in DMEM $10 \%$ FBS supplemented with $1 \%$ Glutamax-I (Invitrogen).

\section{Viruses}

Two ZIKV strains were used to investigate the antiviral potential of pomegranate: the 1947 Uganda MR766 and the 2013 French Polynesia HPF2013, representing the African and the Asian lineages respectively. The viruses were produced via the transfection of 293T cells with 2 plasmids (pCDNA6.2 Zika MR766 Intron3115 HDVr MEG 0709165 and pCDNA6.2 Zika HPF2013 3864,9388Intron HDVr MEG091316 2) kindly provided by Prof. F. Di Cunto and Prof. M. J. Evans, and were propagated and titered in Vero cells, as described in Francese et al. [26]. The HSV-2 strain (ATCC VR-540) was propagated, collected, and titrated, via plaque assay, on Vero cells [33]. The VACV, ATCC VR-1354 strain was propagated, collected, and titrated, via plaque assay, on BHK-21 cells.

\section{Viability assay}

Cell viability was assessed using the MTS assay, as described in Donalisio et al. [34]. PGL8, PGAut85, and PGSum85 were resuspended in a DMSO $/ \mathrm{H}_{2} \mathrm{O}$ solution $(50 \% / 50 \%)$, at $10 \mathrm{mg} / \mathrm{mL}$ concentration; PGAut95 and PGSum95 were resuspended in a DMSO/ $\mathrm{H}_{2} \mathrm{O}$ solution $(87.5 \% / 12.5 \%)$ at $2.5 \mathrm{mg} / \mathrm{mL}$ concentration; ellagic acid was resuspended in DMSO at $10 \mathrm{mg} / \mathrm{mL}$ concentration. The effects of the extract, fractions, and ellagic acid on Vero cells viability were evaluated at 24 and 72 h. $\mathrm{CC}_{50}$ and $95 \% \mathrm{Cl}$ were determined using Prism 5 software (Graph-Pad Software).

\section{Inhibition assays}

The anti-ZIKV activity of the extract, fractions, and ellagic acid was determined using a viral plaque reduction assay on Vero cells as described in Francese et al. [26]. For the HSV-2 and VACV plaque reduction assays, the cells were infected with virus at $\mathrm{MOI} 0.001$ and $0.006 \mathrm{PFU} /$ cell, respectively; the cells were fixed and the plaques were counted at 24 (HSV-2) and $72 \mathrm{~h}$ (VACV) post infection. PGL8, PGAut85, and PGSum85 were resuspended in a DMSO $/ \mathrm{H}_{2} \mathrm{O}$ solution $(50 \% / 50 \%)$ at $10 \mathrm{mg} / \mathrm{mL}$ concentration; PGAut95 and PGSum95 were resuspended in a $\mathrm{DMSO} / \mathrm{H}_{2} \mathrm{O}$ solution $(87.5 \% / 12.5 \%)$ at $2.5 \mathrm{mg} / \mathrm{mL}$ concentration. Betulinic acid, oleanolic acid, ursolic acid, and apigenin were resuspended in a DMSO $/ \mathrm{H}_{2} \mathrm{O}$ solution $(70 \% / 30 \%)$ at $7 \mathrm{mg} / \mathrm{mL}$ concentration; apigenin 7-O-glucoside, luteolin, luteolin 4-O-glucoside, luteolin 7$\mathrm{O}$-glucoside, quercetin 3-O-glucoside, rutin, and ellagic acid were resuspended in DMSO at $10 \mathrm{mg} / \mathrm{mL}$ concentration. The concentrations that reduced viral infectivity by $50 \%$ (half maximal effective concentration, $\mathrm{EC}_{50}$ ) and concentrations that reduced viral infectivity by $90 \%$ (effective concentration-90, $\mathrm{EC}_{90}$ ) were calculated using the software Prism. The results are reported for 3 independent experiments. The selectivity index (SI) was calculated as the ratio $\mathrm{CC}_{50} / \mathrm{EC}_{50}$.

\section{Virus inactivation assay}

Ellagic acid preparations were investigated for their ability to directly inactivate ZIKV particles at $4{ }^{\circ} \mathrm{C}$ and $37^{\circ} \mathrm{C}$ [26]. Ellagic acid was resuspended in DMSO at $10 \mathrm{mg} / \mathrm{mL}$ concentration.

\section{Time-of-addition assays}

Serial dilutions of ellagic acid were either added to Vero cells before infection for $2 \mathrm{~h}$ at $37^{\circ} \mathrm{C}$, during infection with MR766 (MOI 0.005 ), or after the infection [33]. Ellagic acid was resuspended in DMSO at $10 \mathrm{mg} / \mathrm{mL}$ concentration.

\section{Immunofluorescence assay}

Vero cells that were seeded on coverslips were treated with serial doses of plant-isolated ellagic acid for $2 \mathrm{~h}$ prior to infection, for $2 \mathrm{~h}$ during infection with MR766 (MOI 1), and for $30 \mathrm{~h}$ after the absorption process, at $37^{\circ} \mathrm{C}$. The experiment was performed as described in Francese et al. [26], with the exception of the nucleic staining, which was performed using DAPI (Sigma-Aldrich) $0.5 \mathrm{\mu g} / \mathrm{mL}$ for $10 \mathrm{~min}$ at room temperature. Ellagic acid was resuspended in DMSO at $10 \mathrm{mg} / \mathrm{mL}$ concentration. 


\section{Virus yield reduction assay}

The experiment was conducted as described in Francese et al. [26]. Ellagic acid was resuspended in DMSO at $10 \mathrm{mg} / \mathrm{mL}$ concentration.

\section{Binding assay}

The experiment was conducted as described in Francese et al. [26]. Ellagic acid was resuspended in DMSO at $10 \mathrm{mg} / \mathrm{mL}$ concentration.

\section{Statistical analysis}

Antiviral data were analyzed using the Student's t-test and F-test on GraphPad Prism version 5.00 software, as appropriate. The Student's t-test was used to compare viral titers in virus inactivation assays. Significance was reported for $p$-value $<0.05$. Principal component analysis was carried out using Statistica 10 (StatSoft. Inc.) software. Sequence quality and alignment were performed as reported by Marengo et al. [16].

\section{Supporting Information}

Anti-ZIKV activity of a reference pomegranate leaf ethanolic extract PGL8 (Fig. 1S); cell viability assays (Fig. 2S); LC chromatograms of the pomegranate leaf extract PGL8 (Fig. 3S); GC-MS chromatograms of the pomegranate leaf extract PGL8 (Fig. 4S); comparison of ITS sequences between the 11 P. granatum samples (Fig. 5S); comparison of psbA-trnH sequences between the 11 P. granatum samples (Fig.6S); anti-MR766 activity of PGSum85, PGSum95, PGAut85, and PGAut95 (Fig. 7S); ${ }^{1} \mathrm{H}$ $600 \mathrm{MHz}$ NMR of ellagic acid isolated with LC-Prep and of the commercial standard reference (Fig. 8S); inactivation of MR766 particles by isolated ellagic acid (Fig. 9S); effect of isolated ellagic acid on virus binding to cells (Fig. 10S); location, coordinates, and code of pomegranate leaf samples (Table 1S); concentration of phenolic compounds and triterpenes in the different pomegranate leaf extracts and in the fractions (Table 2S); list of the sequences obtained from $P$. granatum samples deposited in GenBank (Table 3S); list of primers used in PCR and sequencing (Table 4S); quantification method, linearity range, $R^{2}$, and calibration curve of the main compounds by UV and SRM methods (Table 5S); and target ion, qualifier ions, linearity range, $R^{2}$, and calibration curve of triterpenoids quantified by GC-MS (Table 6S) are available as Supporting Information.

\section{Contributors' Statement}

Conception and design: C. Sanna; C. Bertea; C. Cagliero; B. Sgorbini; D. Lembo; M. Donalisio; P. Rubiolo. Data collection: C. Sanna; S. Acquadro; A. Civra; A. Marengo; R. Francese; M. Rittà. Analysis and interpretation: S. Acquadro; A. Civra; A. Marengo; R. Francese; M. Rittà; C. Cagliero; C. Sanna; C. Bertea; B. Sgorbini; D. Lembo; M. Donalisio; P. Rubiolo. Statistical analysis: S. Acquadro; A. Civra; A. Marengo; R. Francese; M. Rittà; C. Cagliero; C. Bertea; B. Sgorbini; D. Lembo; M. Donalisio; P. Rubiolo. Drafting of the manuscript: S. Acquadro; A. Civra; A. Marengo; R. Francese; M. Rittà. Critical revision of the manuscript: $C$. Sanna; C. Bertea; C. Cagliero; B. Sgorbini; D. Lembo; M. Donalisio; P. Rubiolo.
Acknowledgements

This work was supported by the Ricerca Locale (ex-60\% 2018) grant from the University of Turin, Turin, Italy.

\section{Conflict of Interest}

The authors declare that they have no conflict of interest.

\section{References}

[1] Saiz JC, Vazquez-Calvo A, Blazquez AB, Merino-Ramos T, EscribanoRomero E, Martin-Acebes MA. Zika virus: the latest newcomer. Front Microbiol 2016; 7: 496

[2] WHO. Zika virus [WWW Document], n.d. Available at https://www.who. int/news-room/fact-sheets/detail/zika-virus. Accessed April 5, 2020

[3] Blázquez AB, Saiz JC. Neurological manifestations of Zika virus infection. World J Virol 2016; 5: 135-143

[4] Batista MN, Braga ACS, Campos GRF, Souza MM, Matos RPA, Lopes TZ, Candido NM, Lima MLD, Machado FC, Andrade STQ, Bittar C, Nogueira ML, Carneiro BM, Mariutti RB, Arni RK, Calmon MF, Rahal P. Natural products isolated from oriental medicinal herbs inactivate Zika virus. Viruses 2019; 11: 49

[5] Fellah B, Bannour M, Rocchetti G, Lucini L, Ferchichi A. Phenolic profiling and antioxidant capacity in flowers, leaves and peels of Tunisian cultivars of Punica granatum L. J Food Sci Technol 2018; 55: 3606-3615

[6] Vucic V, Grabez M, Trchounian A, Arsic A. Composition and potential health benefits of pomegranate: a review. Curr Pharm Des 2019; 25: 1817-1827

[7] Howell AB, D'Souza DH. The pomegranate: Effects on bacteria and viruses that influence human health. Evid Based Complement Alternat Med 2013; 2013: 606212

[8] Arunkumar J, Rajarajan S. Study on antiviral activities, drug-likeness and molecular docking of bioactive compounds of Punica granatum L. to herpes simplex virus-2 (HSV-2). Microb Pathog 2018; 118: 301-309

[9] Haidari M, Ali M, Ward Casscells S, Madjid M. Pomegranate (Punica granatum) purified polyphenol extract inhibits influenza virus and has a synergistic effect with oseltamivir. Phytomedicine 2009; 16: 1127-1136

[10] Neurath AR, Strick N, Li YY, Debnath AK. Punica granatum (Pomegranate) juice provides an HIV-1 entry inhibitor and candidate topical microbicide. BMC Infect Dis 2004; 4: 41

[11] Bekir J, Mars M, Souchard JP, Bouajila J. Assessment of antioxidant, antiinflammatory, anti-cholinesterase and cytotoxic activities of pomegranate (Punica granatum) leaves. Food Chem Toxicol 2013; 55: 470-475

[12] Boggula N, Peddapalli H. Phytochemical analysis and evaluation of in vitro antioxidant activity of punica granatum leaves. Int J Pharmacogn Phytochem Res 2017; 9: 1110-1118

[13] Abdulla R, Mansur S, Lai H, Ubul A, Sun G, Huang G, Aisa HA. Qualitative analysis of polyphenols in macroporous resin pretreated pomegranate husk extract by HPLC-QTOF-MS. Phytochem Anal 2017; 28: 465-473

[14] Wu S, Tian L. Diverse phytochemicals and bioactivities in the ancient fruit and modern functional food pomegranate (Punica granatum). Molecules 2017; 22: 1606

[15] Sumner LW, Amberg A, Barrett D, Beale MH, Beger R, Daykin CA, Fan TWM, Fiehn O, Goodacre R, Griffin JL, Hankemeier T, Hardy N, Harnly J, Higashi R, Kopka J, Lane AN, Lindon JC, Marriott P, Nicholls AW, Reily MD, Thaden J], Viant MR. Proposed minimum reporting standards for chemical analysis Chemical Analysis Working Group (CAWG) Metabolomics Standards Initiative (MSI). Metabolomics 2007; 3: 211-221

[16] Marengo A, Maxia A, Sanna C, Mandrone M, Bertea CM, Bicchi C, Sgorbini B, Cagliero C, Rubiolo P. Intra-specific variation in the littleknown Mediterranean plant Ptilostemon casabonae (L.) Greuter analysed 
through phytochemical and biomolecular markers. Phytochemistry 2019; 161: 21-27

[17] Roy A, Lim L, Srivastava S, Lu Y, Song J. Solution conformations of Zika NS2B-NS3pro and its inhibition by natural products from edible plants. PLoS One 2017; 12: e0180632

[18] Yadav R, Selvaraj C, Aarthy M, Kumar P, Kumar A, Singh SK, Giri R. Investigating into the molecular interactions of flavonoids targeting NS2B-NS3 protease from ZIKA virus through in-silico approaches. J Biomol Struct Dyn 2020. doi:10.1080/07391102.2019.1709546

[19] Wong G, He S, Siragam V, Bi Y, Mbikay M, Chretien M, Qiu X. Antiviral activity of quercetin-3-beta-O-D-glucoside against Zika virus infection. Virol Sin 2017; 32: 545-547

[20] Cui Q, Du R, Anantpadma M, Schafer A, Hou L, Tian J, Davey RA, Cheng $\mathrm{H}$, Rong L. Identification of ellagic acid from plant rhodiola rosea $\mathrm{L}$. as an anti-Ebola virus entry inhibitor. Viruses 2018; 10: 152

[21] Promsong A, Chuenchitra T, Saipin K, Tewtrakul S, Panichayupakaranant P, Satthakarn S, Nittayananta W. Ellagic acid inhibits HIV-1 infection in vitro: Potential role as a novel microbicide. Oral Dis 2018; 24: 249-252

[22] Reddy BU, Mullick R, Kumar A, Sudha G, Srinivasan N, Das S. Small molecule inhibitors of HCV replication from pomegranate. Sci Rep 2014; 4: 5411

[23] Tran TT, Kim M, Jang Y, Lee HW, Nguyen HT, Nguyen TN, Park HW, Le Dang Q, Kim JC. Characterization and mechanisms of anti-influenza virus metabolites isolated from the Vietnamese medicinal plant Polygonum chinense. BMC Complement Altern Med 2017; 17: 162

[24] Shin MS, Kang EH, Lee YI. A flavonoid from medicinal plants blocks hepatitis $B$ virus-e antigen secretion in $\mathrm{HBV}$-infected hepatocytes. Antiviral Res 2005; 67: 163-168

[25] Lee JL, Loe MWC, Lee RCH, Chu JJH. Antiviral activity of pinocembrin against Zika virus replication. Antiviral Res 2019; 167: 13-24
[26] Francese R, Civra A, Ritta M, Donalisio M, Argenziano M, Cavalli R, Mougharbel AS, Kortz U, Lembo D. Anti-Zika virus activity of polyoxometalates. Antiviral Res 2019; 163: 29-33

[27] Ajaegbu EE, Danga SP, Chijoke IU, Okoye FB. Mosquito adulticidal activity of the leaf extracts of Spondias mombin L. against Aedes aegypti L. and isolation of active principles. J Vector Borne Dis 2016; 53: 17-22

[28] Morosetti G, Criscuolo AA, Santi F, Perno CF, Piccione E, Ciotti M. Ellagic acid and Annona muricata in the chemoprevention of HPV-related preneoplastic lesions of the cervix. Oncol Lett 2017; 13: 1880-1884

[29] Garcia-Nino WR, Zazueta C. Ellagic acid: pharmacological activities and molecular mechanisms involved in liver protection. Pharmacol Res 2015; 97: 84-103

[30] Pavlova EL, Simeonova LS, Gegova GA. Combined efficacy of oseltamivir, isoprinosine and ellagic acid in influenza $A(H 3 N 2)$-infected mice. Biomed Pharmacother 2018; 98: 29-35

[31] Marengo A, Maxia A, Sanna C, Bertea CM, Bicchi C, Ballero M, Cagliero C, Rubiolo P. Characterization of four wild edible Carduus species from the Mediterranean region via phytochemical and biomolecular analyses. Food Res Int 2017; 100: 822-883

[32] Rubiolo P, Casetta C, Cagliero C, Brevard H, Sgorbini B, Bicchi C. Populus nigra L. bud absolute: a case study for a strategy of analysis of natural complex substances. Anal Bioanal Chem 2013; 405: 1223-1235

[33] Ghosh M, Civra A, Ritta M, Cagno V, Mavuduru SG, Awasthi P, Lembo D, Donalisio M. Ficus religiosa L. bark extracts inhibit infection by herpes simplex virus type 2 in vitro. Arch Virol 2016; 161: 3509-3514

[34] Donalisio M, Quaranta P, Chiuppesi F, Pistello M, Cagno V, Cavalli R, Volante M, Bugatti A, Rusnati M, Ranucci E, Ferruti P, Lembo D. The AGMA1 poly(amidoamine) inhibits the infectivity of herpes simplex virus in cell lines, in human cervicovaginal histocultures, and in vaginally infected mice. Biomaterials 2016; 85: 40-53 